\title{
Long-term clinical experience with darunavir (2007-2015) in a large cohort of HIV-infected patients in Spain
}

\author{
Berta Pernas, ${ }^{1}$ Marta Grandal, ${ }^{1}$ Andrés Tabernilla, ${ }^{1}$ Purificación Cid, ${ }^{2}$ Sonia \\ Pértega, ${ }^{3}$ Angeles Castro-Iglesias, ${ }^{1}$ Alvaro Mena, ${ }^{1}$ Luis Margusino, ${ }^{2}$ José D. \\ Pedreira, ${ }^{1}$ and Eva Poveda ${ }^{1}$
}

\author{
${ }^{1}$ Division of Clinical Virology, Instituto de Investigación Biomédica de A Coruña (INIBIC)-Complejo \\ Hospitalario Universitario de A Coruña (CHUAC), SERGAS, Universidad de A Coruña, A Coruña, Spain \\ ${ }^{2}$ Service of Pharmacy, Complejo Hospitalario Universitario de A Coruña, SERGAS, A Coruña, Spain \\ ${ }^{3}$ Clinical Epidemiology and Biostatistics Unit, Instituto de Investigación Biomédica de A Coruña (INIBIC)- \\ Complejo Hospitalario Universitario de A Coruña, SERGAS, A Coruña, Spain
}

\begin{abstract}
The clinical experience with the protease inhibitor darunavir/ritonavir (DRV/r) was retrospectively evaluated in a cohort of $173 \mathrm{HIV}+$ patients who initiated antiretroviral treatment including DRV/r (period 2007-2015). The $43.2 \%$ had a CD4 nadir $\leq 100$ cells $/ \mathrm{mm}^{3}, 64.1 \%$ were treatment-experienced, and $36.5 \%$ had failed to $>3$ lines of antiretroviral therapy. Nonetheless, the rate of virological suppression (HIV-RNA $<50$ copies $/ \mathrm{ml}$ ) in naïve patients was $63 \%, 66.7 \%$, and $63.6 \%$ at 48,96 , and 144 weeks, respectively. The rate of virological suppression in treatment-experienced patients was $62.7 \%, 78.7 \%$, and $79.1 \%$ at 48,96 , and 144 weeks, respectively. No differences were observed according to the immunovirological status neither dosage of DRV/r. Most of them (82.6\%) maintained DRV/r treatment. Causes for DRV/r discontinuation were mainly gastrointestinal and cutaneous adverse events (10.5\%), switch to simplification treatment strategies $(3.5 \%)$ and virological failure (1.7\%). These findings demonstrate the prolonged efficacy and tolerability of DRV/r even in multi-treated HIV+ patients with an unfavorable immunovirological status.
\end{abstract}

Key words: HIV infection; darunavir; efficacy; safety 


\section{INTRODUCTION}

The goal of antiretroviral treatment (ART) is to achieve and maintain virological suppression in HIV+ patients. The ART options have been significantly improved in the last years with a progressive introduction of novel highly efficacy antiretroviral drugs with a better safety and tolerability profiles than the previous ones. Now therefore, the selection of an antiretroviral regimen to treat HIV infection can and should be individualized, considering several factors including patient's co-morbidities, adherence, adverse events or baseline drug resistance mutations [DHHS, 2015; EACS, 2015].

Darunavir boosted with ritonavir (DRV/r) has been approved for the treatment of HIV infection by the Food and Drug Administration in 2006 and by the European Medicines Agency in 2007. DRV/r represents a second-generation of protease inhibitors (PIs) with a higher genetic barrier for resistance than the first-generation [Poveda et al., 2006, 2007]. Indeed, due to its proven efficacy in the presence of PIs resistance mutations, the initial target population for DRV/r was treatment-experienced HIV-infected patients with limited therapeutic options [Clotet et al., 2007]. Later, several clinical trials demonstrated its efficacy in both naïve and treatment-experienced HIV+ patients [Madruga et al., 2007; Ortiz et al., 2008]. Indeed, in the last HIV treatment guidelines, a DRV/r-based regimen is a recommended treatment strategy for initial therapy, especially for patients with poor adherence due to its high genetic barrier to resistance [DHHS, 2015; EACS, 2015].

The use of DRV/r as monotherapy was also evaluated as simplification treatment strategy to reduce nucleoside reverse transcriptase inhibitors (NRTIs) toxicity, to prevent the selection of resistance mutations to other drug families and to reduce costs. This strategy is able to maintain HIV-RNA suppression in the long-term in a group of selected HIV+ patients with a stable control of plasma viremia [Katlama et al., 2010; Gazzard et al., 2011; Arribas et al., 2016]. More recently, dual therapy (i.e., DRV/r with raltegravir, lamivudine or etravirine) has shown a good profile of efficacy and safety. Therefore, it could be considered a feasible option for the optimization of ART [Borghetti et al., 2014; Raffi et al., 2014; Vingerhoets et al., 2015].

However, few studies have evaluated the long-term efficacy and safety of regimens including $\mathrm{DRV} / \mathrm{r}$ in the real life and outside clinical trials [Young et al., ; Benea et al., 2014; Biscione et al., 2014; Ribeiro et al., 2014]. Herein, we assessed the clinical experienced with DRV/r based on efficacy, safety and tolerability parameters in a large cohort of HIV+ patients in Northwest Spain since its approval since 2007 until nowadays.

\section{METHODS}

This is a retrospective observational study, which included HIV+ patients over 18 years old in clinical follow-up at the University Hospital of A Coruña (Spain) who have received ART including DRV/r between 2007 and September 2015. The research protocol has been approved by the regional ethic committee ("Comité Ético de Investigación Clínica de Galicia", register code 2014/500) and only patients who have signed the informed consent were included. This hospital attends a reference health area of more than 500,000 citizens and approximately 1,000 HIV+ patients in clinical follow-up.

The clinical experience with DRV/r was retrospectively evaluated. Epidemiological, clinical and immunovirological features of HIV+ patients who had started ART with DRV/r were recorded. Previous exposition to antiretroviral drugs and drug resistance profile, when available, were also recorded. Genotypic resistance testing was performed according to clinical guidelines recommendations. Resistances to the different antiretroviral-family drugs were recorded using the freely available algorithm from Stanford University Drug Resistance database. The efficacy, safety and tolerance of the ART including DRV/r were evaluated during the study period. Efficacy was 
evaluated at 48, 96, and 144 weeks. Patients with suppressed viremia (HIV-RNA $<50$ copies/ml) at time of DRV/r initiation and patients with no data about time under DRV/r regimen were excluded of the efficacy analysis. In addition, patients with less than 48, 96, and 144 weeks of follow-up with DRV/r-based therapy were also excluded of the corresponding analysis, unless discontinuation of $\mathrm{DRV} / \mathrm{r}$ regimen (i.e., due to toxicity).

The statistical analysis was performed using the Statistical Packages for the Social Sciences software (SPSS 19.0, Chicago, IL). Categorical variables are presented as number of cases or percentage and were compared by the $\chi^{2}$ test or Fisheŕs exact test, when appropriate. Continuous variables are expressed as mean (standard deviation) and compared by non-parametric MannWhitney and Kruskal-Wallis test, when appropriate. A $P$-value of $<0.05$ was considered statistically significant.

\section{RESULTS}

A total of $360 \mathrm{HIV}$-infected patients have initiated ART with DRV/r in the period 2007-2015 but only 173 patients have signed the informed consent and therefore could be included in the study. Epidemiological and immunovirological characteristics of these patients were described in Table I. Overall, these patients had a severe immunosuppression with nadir CD4 counts values of $154 \pm 126 \mathrm{cell} / \mathrm{mm}^{3}$; being the CD4 nadir $\leq 100 \mathrm{cells} / \mathrm{mm}^{3}$ in $43.2 \%$ of them. Moreover, $32.1 \%$ of naïve patients initiated treatment with a DRV/r-based therapy at diagnosis time of an AIDS defining disease: Pneumocystis jiroveci pneumonia (35.7\%), tuberculosis (35.7\%), toxoplasmosis (10.7\%), HIV encephalopathy (3.6\%), and others (14.3\%). 
Table I. Baseline Characteristics of HIV-Infected Patients Receiving DRV/r Therapy

\begin{tabular}{|c|c|}
\hline Variables & $\mathrm{N}=173$ \\
\hline \multicolumn{2}{|l|}{ Epidemiological } \\
\hline Male & $131(75.7)$ \\
\hline Mean age (years) & $32.8 \pm 10.1$ \\
\hline \multicolumn{2}{|l|}{ Route of HIV transmission } \\
\hline Heterosexual & $51(30.4)$ \\
\hline MSM & $52(31)$ \\
\hline IDU & $60(35.7)$ \\
\hline Other & $5(3)$ \\
\hline \multicolumn{2}{|l|}{ Nationality } \\
\hline Spanish & $151(88.3)$ \\
\hline European & $2(1.2)$ \\
\hline South-American & $15(8.8)$ \\
\hline African & $3(1.8)$ \\
\hline \multicolumn{2}{|l|}{ Inmunovirological status } \\
\hline Late diagnosis & $67(62)$ \\
\hline CD4 count at HIV diagnosis (cells $/ \mathrm{mm}^{3}$ ) & $288 \pm 245$ \\
\hline CD4 nadir (cells/mm3) & $154 \pm 126$ \\
\hline Viral load at HIV diagnosis (log copies/ml) & $5.87 \pm 6.25$ \\
\hline \multicolumn{2}{|l|}{ CDC classification } \\
\hline Category A & $58(37.7)$ \\
\hline Category B & $26(16.9)$ \\
\hline Category C & $70(45.5)$ \\
\hline \multicolumn{2}{|l|}{ HIV-1 genetic subtype } \\
\hline Subtype B & $31(17.9)$ \\
\hline Subtype F & $32(18.5)$ \\
\hline Subtype C & $3(1.7)$ \\
\hline Unknown subtype & $107(61.8)$ \\
\hline Comorbidity & $57.2 \%$ \\
\hline \multicolumn{2}{|l|}{ Viral hepatitis co-infection } \\
\hline HBsAg positive & $4(2.3)$ \\
\hline Antibodies HCV & $65(37.6)$ \\
\hline HCV-RNA positive & $50(28.9)$ \\
\hline \multicolumn{2}{|l|}{ Neuropsyquiatric morbidity } \\
\hline Drug-consumption related disorders & $11(6.4)$ \\
\hline Anxious-depressive syndrome & $31(17.9)$ \\
\hline Psychotic syndrome & $7(4)$ \\
\hline Other & $3(1.7)$ \\
\hline $\begin{array}{l}\text { Chronic kidney disease (estimated glomerular } \\
\text { filtration rate } 30-60 \mathrm{ml} / \mathrm{min} \text { ) }\end{array}$ & $12(6.9)$ \\
\hline
\end{tabular}

Data are expressed as n (\%). 
The presence of viral hepatitis co-infection, neuropsyquiatric and/or chronic kidney comorbidities was recognized in $57.2 \%$ of patients (Table I). Transaminase values were significantly higher in HIV-HCV co-infected patients (mean values of AST and ALT of $46 \pm 70$ and $52 \pm 93 \mathrm{mg} / \mathrm{dl}$, respectively) compared to HIV mono-infected patients (median values of $25 \pm 6$ and $26 \pm 11 \mathrm{mg} / \mathrm{dl}$, respectively; $P=0.002$ [for AST] and $P=0.011$ [for ALT]). In addition, cardiovascular risk factors were present with the following distribution: tobacco-consumption (37\%), dyslipidaemia (25.6\%), hypertension (14\%), and diabetes mellitus (1.7\%) while $17.5 \%$ of them have two or more cardiovascular risk factors. Patients with dyslipidaemia had the following lipid profile (mean values): $212 \pm 39 \mathrm{mg} / \mathrm{dl}$ of cholesterol, $44 \pm 12 \mathrm{mg} / \mathrm{dl}$ HDL-cholesterol, $123 \pm 38 \mathrm{mg} / \mathrm{dl}$ LDL cholesterol, and $232 \pm 125 \mathrm{mg} / \mathrm{dl}$ triglycerides.

Overall, $35.8 \%$ of patients were naïve to ART and $64.1 \%$ were treatment-experienced. Of them, $27.8 \%$ had been exposed to $\leq 3$ ART regimens and $36.4 \%$ to $>3$ before DRV/r initiation. The mean time under a DRV/r-based therapy was $38 \pm 27$ months. Detailed information about immunovirological status, time since HIV infection, time under ART (including time under DRV/r-based therapy), previous ART regimens and reasons for discontinuation of these previous therapies in treatment-experience patients were exposed in Table II. 
Table II. Antiretroviral Therapy Characteristics and Resistance Profile in Patients Receiving DRV/r Therapy According Previous ART Exposure

\begin{tabular}{|c|c|c|c|}
\hline & Naïve $(n=62)$ & $\begin{array}{l}\text { Treatment-experienced } \leq 3 \\
\text { ART lines }(n=48)\end{array}$ & $\begin{array}{l}\text { Treatment-experienced }>3 \\
\text { ART lines }(n=63)\end{array}$ \\
\hline $\begin{array}{l}\text { Time with HIV-infection until DRV/r } \\
\text { initiation (months) }\end{array}$ & $17.5 \pm 35.6$ & $103.8 \pm 76.2$ & $203.7 \pm 67.8$ \\
\hline $\begin{array}{l}\text { Time with ART until DRV/r initiation } \\
\text { (months) }\end{array}$ & NA & $62.7 \pm 47.6$ & $141.1 \pm 44.4$ \\
\hline $\mathrm{CD} 4<200$ cells $/ \mathrm{mm}^{3}$ at $\mathrm{DRV} / \mathrm{r}$ initiation $(\%)$ & 43.3 & 23.7 & 31.5 \\
\hline $\begin{array}{l}\text { HIV-RNA > 100,000 copies/ml at DRV } \\
\text { initiation }(\%)\end{array}$ & 68.3 & 38.9 & 25 \\
\hline $\begin{array}{l}\text { Suppressed viral load (HIV-RNA }<50 \\
\text { copies/ml) at DRV/r initiation (\%) }\end{array}$ & 0 & 56.1 & 41.9 \\
\hline Time with DRV/r regimen (months) & $25.9 \pm 16.9$ & $38.8 \pm 26.3$ & $49.7 \pm 31.9$ \\
\hline \multicolumn{4}{|l|}{ Type of DRV/r regimen (\%) } \\
\hline Triple therapy & 100 & 80.4 & 71 \\
\hline Dual therapy & 0 & 2.2 & 9.7 \\
\hline Monotherapy & 0 & 17.4 & 19.4 \\
\hline \multicolumn{4}{|l|}{ Dosage of DRV/r (\%) } \\
\hline $800 \mathrm{QD}$ & 100 & 93.3 & 62.7 \\
\hline $600 \mathrm{BID}$ & 0 & 6.7 & 37.3 \\
\hline \multicolumn{4}{|l|}{ Previous ART regimens $(\%)$} \\
\hline NNRTIs-based regimen & NA & 60.9 & 83.9 \\
\hline PIs-based regimen & NA & 60.9 & 98.4 \\
\hline INIs-based regimen & NA & 6.5 & 6.5 \\
\hline \multicolumn{4}{|l|}{$\begin{array}{l}\text { Reason for discontinuation of previous ART } \\
\text { regimen }(\%)\end{array}$} \\
\hline Poor adherence & NA & 17.4 & 17.7 \\
\hline Virological failure & NA & 21.7 & 35.5 \\
\hline Toxicity & NA & 41.3 & 11.3 \\
\hline Simplification & NA & 6.5 & 27.4 \\
\hline Not available data & NA & 13 & 8.1 \\
\hline \multicolumn{4}{|l|}{ Resistance profile (\%) } \\
\hline Baseline NRTIs resistance & 3.4 & 0 & 0 \\
\hline Baseline NNRTIs resistance & 3.4 & 7.7 & 0 \\
\hline Baseline PIs resistance & 1.7 & 0 & 0 \\
\hline NRTIs resistance at virological failure & NA & 50 & 86.1 \\
\hline NNRTIs resistance at virological failure & NA & 66.7 & 76.5 \\
\hline PIs resistance at virological failure & NA & 0 & 58.3 \\
\hline
\end{tabular}

$\mathrm{DRV} / \mathrm{r}$, darunavir boosted with ritonavir; ART, antiretroviral treatment; NA, not applicable; $800 \mathrm{QD}, 800 \mathrm{mg}$ of darunavir $+100 \mathrm{mg}$ of ritonavir, once a day; $600 \mathrm{BID}, 600 \mathrm{mg}$ of darunavir $+100 \mathrm{mg}$ of ritonavir, twice a day; NNRTIs, non-nucleoside reverse transcriptase inhibitors; PIs, protease inhibitors; INIs, integrase inhibitors; NRTIs, nucleoside reverse transcriptase inhibitors. 
Baseline resistance test was performed in a $42.8 \%$ of patients included in the study. Regarding treatment-experienced patients, resistance test was performed in $63.6 \%$ of patients at virological failure time. Drug resistance to NRTIs, non-nucleoside reverse transcriptase inhibitors (NNRTIs) and PIs drugs at baseline and at virological failure were described in Table II.

The majority of patients $(83.7 \%)$ initiated DRV/r in triple combination therapy, $12.2 \%$ as monotherapy and $4.1 \%$ as dual therapy. The mean of CD4 counts at the DRV/r initiation was $345 \pm 294$ cells $/ \mathrm{mm}^{3}$ and the mean viral load was $5.52 \pm 5.76 \mathrm{log}$ copies $/ \mathrm{ml}$. All naïve patients received dosage of $800 \mathrm{mg}$ of darunavir boosted with $100 \mathrm{mg}$ of ritonavir once a day (800 QD). Regarding treatment-experienced patients, 76.4\% received 800 QD and 23.6\% received $600 \mathrm{mg}$ of darunavir boosted with $100 \mathrm{mg}$ of ritonavir twice a day (600 BID).

Overall, the virological suppression (HIV-RNA $<50$ copies/ml) was achieved in $62.9 \%$ at 48 weeks and $73.8 \%$ at 96 and 144 weeks of DRV/r treatment (excluding patients with suppressed viremia at the moment of $\mathrm{DRV} / \mathrm{r}$ initiation). The rate of virological suppression in naïve patients was $63 \%, 66.7 \%$, and $63.6 \%$ at 48,96 , and 144 weeks, respectively. The rate of virological suppression in treatment-experienced patients was $62.7 \%, 78.7 \%$, and $79.1 \%$ at 48,96 , and 144 weeks, respectively. No significant differences in virological suppression were observed according to immunovirological status at DRV/r initiation neither the dosage of DRV/r, although efficacy is higher in treatment-experienced patients with DRV/r 600 BID (Table III). Regarding treatmentexperienced patients, efficacy at 48 weeks was $62.5 \%$ for those with triple therapy and $66.7 \%$ for those with dual therapy, and no significant differences were observed between both groups $(P=0.999)$. 
Table III. Virological Efficacy (HIV-RNA $<50$ copies/mL) at 48, 96, and 144 Weeks According to the ImmunoVirological Status and DRV/r Dosage

\begin{tabular}{|c|c|c|c|}
\hline & Naïve & Treatment-experienced & $P$ \\
\hline & . & & \\
\hline 48 weeks & $\mathrm{N}=54$ & $\mathrm{~N}=51$ & \\
\hline Efficacy $(\%)$ & 63 & 62.7 & 0.982 \\
\hline \multirow[t]{2}{*}{$\mathrm{CD} 4\left(\right.$ cells $\left./ \mathrm{mm}^{3}\right)$ at $\mathrm{DRV} / \mathrm{r}$ initiation } & & & $0.569^{*}$ \\
\hline & & & $0.757 * *$ \\
\hline $\mathrm{CD} 4 \leq 200$ & 56.5 & 57.1 & \\
\hline CD4 >200 & 67.7 & 62.5 & \\
\hline \multirow[t]{2}{*}{ HIV-RNA (copies/ml) at DRV/r initiation } & & & $0.229^{*}$ \\
\hline & & & $0.526 * *$ \\
\hline HIV-RNA $\leq 100,000$ & 76.5 & 66.7 & \\
\hline HIV-RNA > 100,000 & 56.8 & 53.3 & \\
\hline Dosage of DRV/r & & & $0.352 * *$ \\
\hline $800 \mathrm{QD}$ & 63 & 58.6 & \\
\hline $600 \mathrm{BID}$ & NA & 71.4 & \\
\hline 96 weeks & $\mathrm{N}=33$ & $\mathrm{~N}=47$ & \\
\hline Efficacy $(\%)$ & 66.7 & 78.7 & 0.228 \\
\hline \multirow[t]{2}{*}{$\mathrm{CD} 4\left(\right.$ cells $\left./ \mathrm{mm}^{3}\right)$ at $\mathrm{DRV} / \mathrm{r}$ initiation } & & & $0.719 *$ \\
\hline & & & $0.999 * *$ \\
\hline $\mathrm{CD} 4 \leq 200$ & 71.4 & 78.9 & \\
\hline CD4 >200 & 63.2 & 81.8 & \\
\hline HIV-RNA (copies/ml) at DRV/r initiation & & & $0.456^{* * * *}$ \\
\hline HIV-RNA $\leq 100,000$ & 76.9 & 81.8 & \\
\hline HIV-RNA > 100,000 & 60 & 71.4 & \\
\hline Dosage of DRV/r & & & $0.150 * *$ \\
\hline $800 \mathrm{QD}$ & 66.7 & 69.2 & \\
\hline $600 \mathrm{BID}$ & NA & 90 & \\
\hline 144 weeks & $\mathrm{N}=22$ & $\mathrm{~N}=43$ & \\
\hline Efficacy $(\%)$ & 63.6 & 79.1 & 0.180 \\
\hline \multirow[t]{2}{*}{$\mathrm{CD} 4\left(\right.$ cells $\left./ \mathrm{mm}^{3}\right)$ at $\mathrm{DRV} / \mathrm{r}$ initiation } & & & $0.999 *$ \\
\hline & & & $0.701 * *$ \\
\hline $\mathrm{CD} 4 \leq 200$ & 63.6 & 82.4 & \\
\hline $\mathrm{CD} 4>200$ & 63.6 & 75 & \\
\hline HIV-RNA (copies/ml) at DRV/r initiation & & & $0.999 * * * *$ \\
\hline HIV-RNA $\leq 100,000$ & 60 & 77.4 & \\
\hline HIV-RNA > 100,000 & 66.7 & 83.3 & \\
\hline Dosage of DRV/r & & & $0.149^{* *}$ \\
\hline 800 QD & 63.6 & 66.9 & \\
\hline $600 \mathrm{BID}$ & NA & 89.5 & \\
\hline
\end{tabular}


All naïve patients with baseline resistance achieved virological suppression at 48 weeks. Treatment-experienced patients with previous resistance to NRTIs achieved virological suppression in $76 \%, 78.3 \%$, and $76.2 \%$ at 48,96 , and 144 weeks, respectively. Those with previous resistance to NNRTIs achieved virological suppression in $58.3 \%, 71.4 \%$, and $68.4 \%$ at 48, 96, and 144 weeks, respectively. Interestingly, treatment-experienced patients with previous resistance to PIs achieved virological suppression in $83.3 \%$ at 48 and 96 weeks and $82.4 \%$ at 144 weeks.

Of note, $47.1 \%$ of treatment-experienced patients had undetectable viremia at the time of $\mathrm{DRV} / \mathrm{r}$ initiation. All patients with triple and dual therapy and suppressed viremia at DRV/r initiation maintained virological suppression during follow-up. In two patients receiving DRV/r as monotherapy, the addition of two NRTI was required due to virological failure but in both cases they achieved virological suppression afterwards.

During the follow-up, $9.3 \%$ of patients who had initiated triple-therapy with DRV/r switch to $\mathrm{DRV} / \mathrm{r}$ monotherapy while $8.5 \%$ switch to dual therapy with DRV/r. In all these cases, patients maintained virological suppression after simplification.

Overall, $82.6 \%$ of patients maintained DRV/r therapy during the study period. The main causes for DRV/r discontinuation were adverse events (10.5\%), switch to simplification strategies $(3.5 \%)$, virological failure (1.7\%; all of them with HIV-RNA values $<200$ copies $/ \mathrm{ml}$ ) and drug-drug interactions (1.7\%). Pharmacological interactions were present with telaprevir, pulmonary hypertension treatment and anti-deppressive medication.

Regard the safety and tolerability under DRV/r, the most part of patients $(89.5 \%)$ had no relevant adverse events. The main recognized adverse events were gastrointestinal (3.6\%) and cutaneous $(2.4 \%)$ while $4.5 \%$ had other adverse events including dyslipidaemia or dizziness, which are described in detail in Table IV. Only two patients of all who discontinued therapy with $\mathrm{DRV} / \mathrm{r}$ due to toxicity were taking $600 \mathrm{BID}$. 
Table IV. Toxicity in Patients Who Discontinued DRV/r-Based Therapy

\begin{tabular}{|c|c|c|}
\hline ART regimen & $\mathrm{N}(\%)$ & Toxicity \\
\hline Overall & $173(100)$ & $10.5 \%$ \\
\hline \multirow[t]{2}{*}{ Triple-therapy } & $145(83.8)$ & $12 \%$ \\
\hline & & Cutaneous $(n=3)$ \\
\hline \multirow[t]{2}{*}{$\mathrm{TDF} / \mathrm{FTC}+\mathrm{DRV} / \mathrm{r}$} & $92(53.2)$ & Gastrointestinal $(\mathrm{n}=2)$ \\
\hline & & Other $^{\mathrm{a}}(\mathrm{n}=6)$ \\
\hline \multirow{2}{*}{$\mathrm{ABC} / 3 \mathrm{TC}+\mathrm{DRV} / \mathrm{r}$} & \multirow{2}{*}{$29(16.8)$} & Gastrointestinal $(\mathrm{n}=2)$ \\
\hline & & $\operatorname{Other}^{\mathrm{b}}(\mathrm{n}=2)$ \\
\hline $\mathrm{RAL}+\mathrm{ETR}+\mathrm{DRV} / \mathrm{r}$ & $8(4.6)$ & \\
\hline $\mathrm{RAL}+\mathrm{MVC}+\mathrm{DRV} / \mathrm{r}$ & $4(2.3)$ & \\
\hline $\mathrm{TDF} / \mathrm{FTC}+\mathrm{RAL}+\mathrm{DRV} / \mathrm{r}$ & $6(3.5)$ & Cutaneous $(\mathrm{n}=1)$ \\
\hline $\mathrm{TDF} / \mathrm{FTC}+\mathrm{MVC}+\mathrm{DRV} / \mathrm{r}$ & $2(1.2)$ & Gastrointestinal $(\mathrm{n}=1)$ \\
\hline Other & $4(2.2)$ & \\
\hline Dual therapy & $7(4.1)$ & $0 \%$ \\
\hline $\mathrm{MVC}+\mathrm{DRV} / \mathrm{r}$ & $2(1.2)$ & \\
\hline $3 \mathrm{TC}+\mathrm{DRV} / \mathrm{r}$ & $1(0.6)$ & \\
\hline $\mathrm{RAL}+\mathrm{DRV} / \mathrm{r}$ & $3(1.7)$ & \\
\hline $\mathrm{ETR}+\mathrm{DRV} / \mathrm{r}$ & $1(0.6)$ & \\
\hline \multirow[t]{2}{*}{ Monotherapy } & $21(12.1)$ & $4.8 \%$ \\
\hline & & Gastrointestinal $(\mathrm{n}=1)$ \\
\hline
\end{tabular}

TDF/FTC, tenofovir and emtricitabine coformulated; ABC/3TC, abacavir and lamivudine coformulated; RAL, raltegravir; ETR, etravirine; MVC, maraviroc; 3TC, lamivudine.

a Other includes: dyslipidemia, trombopenia, renal toxicity (two patients), dizziness and sexual disfunction.

${ }^{\mathrm{b}}$ Other: not specified type of toxicity.

\section{DISCUSSION}

DRV/r represents the second generation of PIs with demonstrated antiviral activity against HIV+ treatment-naïve and experienced patients harbouring protease resistance mutations to the first PIs generation [Clotet et al., 2007; Madruga et al., 2007; Ortiz et al., 2008]. The efficacy and safety of DRV/r have been extensively demonstrated in different clinical trials and current HIV treatment guidelines considered DRV/r in combination with tenofovir/emtricitabine as a recommended regimen for treatment-naïve patients [DHHS, 2015; EACS, 2015]. However, there are few studies evaluating the long-term efficacy and safety of DRV/r in the real-life setting, and all of them only include treatment-experienced patients [Young et al., ; Benea et al., 2014; Biscione et al., 2014; Ribeiro et al., 2014].

Herein, we retrospectively evaluated the clinical experience with DRV/r since its approval in 2007 until September 2015 in 173 HIV+ patients in clinical follow-up in Northwest Spain. This patient population is characterized for high HIV-RNA levels at the moment of DRV/r initiation (mean of $5.52 \log$ copies/ml) and severe immunosuppression in most cases $(62 \%$ had a late diagnosis and $43 \%$ had CD4 nadir $<100$ cells $/ \mathrm{mm}^{3}$ ). Moreover, $64.1 \%$ were treatment-experienced and of them $36.5 \%$ had been exposed to $>3$ ART regimens. However, and despite this unfavourable clinical status, the overall rate of virological suppression was $62.9 \%$ at 48 weeks and $73.8 \%$ at 96 and 144 weeks of DRV/r-based therapy. No differences in efficacy were observed between naïve and treatment-experienced patients at 48 weeks (63\% vs. $62.7 \%, P=0.982)$, at 96 weeks $(66.7 \%$ vs. $78.7 \%, P=0.228)$ and 144 weeks $(63.6 \%$ vs. $79.1 \%, P=0.180)$. These data 
highlight the high potency of DRV/r irrespectively of the HIV-RNA levels and the immune status but also its ability to be used in rescue therapies for patients who have failed several ART regimens. Of note, only $1.7 \%$ of patients discontinue $\mathrm{DRV} / \mathrm{r}$ treatment due to virological failure and all of them with HIV-RNA values $<200$ copies $/ \mathrm{ml}$.

In most cases DRV/r was used as part of triple therapy strategies (83.7\%) but also in monotherapy (12.2\%) and dual therapy (4.1\%). DRV/r may be particularly suited for both monotherapy or dual therapy due to its high genetic barrier and its favourable safety and pharmacokinetic profile that allow to be administered once daily [Rabi et al., 2013]; and the recent introduction of the coformulation of darunavir with cobicistat in only one pill may optimize dosage and adherence. Both strategies might be particularly attractive in cases of NRTIs-related intolerance or toxicity and its use in these setting is recognized in some guidelines [EACS, 2015; Panel de expertos de GeSIDA, 2015]. Dual and monotherapy were used only in treatmentexperienced patients in our study. The rate of virological suppression in patients with dual therapy was $66.7 \%$ at 48 weeks, and no differences in efficacy were observed compared to treatmentexperienced patients with triple therapy. In addition, all patients under dual therapy and virological suppression at DRV/r initiation, maintained efficacy during the follow-up. In the case of DRV/r monotherapy, randomized clinical trials and experience in the real life have shown optimized results in simplification strategies in selected $\mathrm{HIV}+$ patients (absence of chronic hepatitis B infection, HIV plasmatic viral load $<50$ copies/ml during at least 6 months and absence of resistance mutations in protease gene or previous virological failure to PIs [Katlama et al., 2010; Santos et al., 2012; Arribas et al., 2016]. In this study, all but two patients receiving DRV/r monotherapy maintain virological suppression (probably due to inadequate adherence).

$\mathrm{DRV} / \mathrm{r}$ was well tolerated in clinical trials, with a better profile than other PIs regarding to diarrhoea, gastrointestinal tolerability and lipid concentrations. Treatment discontinuation due to adverse events in clinical trials varies between 4\% and 7\% [Clotet et al., 2007; Madruga et al., 2007]. In this study, $10.5 \%$ of patients have discontinued DRV/r treatment due to adverse events being gastrointestinal toxicity $(3.6 \%)$ and cutaneous reaction $(2.4 \%)$ the most frequent. Although this percentage is slightly higher than in other studies, this might be due to the specific inclusion criteria required for clinical trials that do not reflect the real-life scenario. Of note, those patients under DRV/r monotherapy or dual therapy had little adverse events. Although the number of patients under NRTIs-sparing regimen is limited, some of these adverse reactions might be potentially attribute to the use of NRTI.

There are some limitations in this study. This is a retrospective and observational study, therefore, these results could not be compared with other obtained in clinical trials or study cohorts due to the heterogeneity of the study populations, studies design, inclusion criteria or endpoints. In addition, only those patients who have signed informed consent were included in the study, but they do not represent all the patients treated with a DRV/r-based regimen, therefore, possible bias could exist. Moreover, data of drug resistance mutations were not available in more than a half of patients (at baseline) and almost $40 \%$ (at virological failure). However, considering the rates of virological suppression in treatment-experienced patients, over $80 \%$ in patients with previous PIs resistances, it seems that if drug resistance mutations were present, they had little impact on the virological response to DRV/r. Regarding evaluation of safety, grade of toxicity of DRV/r was not recorded in most of patients, and it is possible that mild adverse events were present in some of them. Nonetheless, this mild toxicity would not have relevant clinical consequences as most of the patients maintained DRV/r-based therapy.

In conclusion, this study demonstrated the prolonged efficacy and safety profile of DRV/r for the treatment of HIV-infected patients even in patients with an unfavourable viro-immunological status in the real-life setting. Moreover, DRV/r might be considered a good therapeutic option for those patients who had failed to several ART regimens or for those with intolerance to other ART drugs as mono- or dual-based therapies. 


\section{ACKNOWLEDGMENTS}

We would like to thank Biobank of A Coruña (SERGAS) for providing us the technical, ethical and legal advice necessary for the development of our research.

\section{REFERENCES}

Arribas JR, Girard PM, Paton N, Winston A, Marcelin AG, Elbirt D, Hill A, Hadacek MB. 2016. Efficacy of protease inhibitor monotherapy vs. triple therapy: Meta-analysis of data from 2303 patients in 13 randomized trials. HIV Med 17:358-367.

Benea OE, Streinu-Cercel A, Dorobăţ C, Rugină S, Negruţiu L, Cupşa A, Duiculescu D, Chiriac C, Itu C, Prisăcariu LJ, Iosif F. 2014. Efficacy and safety of darunavir (Prezista(®)) with low-dose ritonavir and other antiretroviral medications in subtype F HIV-1 infected, treatment-experienced subjects in Romania: A post-authorization, open-label, one-cohort, non-interventional, prospective study. Germs 4:59-69.

Biscione FM, Westin MR, Ribeiro KM, Estevam DL, Cardoso SW, Tenore SB, Neto LF, Alencastro PR, Suffert TA, de Moraes MJ, Barbosa AN, Morejón KM, de Arruda EA, Silveira JM, Neto JL, Greco DB, Tupinambás U. 2014. Virologic and immunologic effectiveness at 48 weeks of darunavir-ritonavir-based regimens in treatment-experienced persons living with HIV-1 infection in clinical practice: A multicenter Brazilian cohort. J Int Assoc Provid AIDS Care 13:63-68.

Borghetti A, Mondi A, Piccoli B, Gagliardini R, Lamonica S, Ciccareli N, D́Avino A, Pallavicini F, Cauda R, De Luca A, Fabbiani M, Di Giambenedetto S. 2014. Switching to lamivudine plus darunavir/r dual therapy in a cohort of treatment-experienced HIV positive patients: The experience of an Italian centre. J Int AIDS Soc 17:19817.

Clotet B, Bellos N, Molina JM, Cooper D, Goffard JC, Lazzarin A, Wöhrmann A, Katlama C, Wilkin T, Haubrich R, Cohen C, Farthing C, Jayaweera D, Markowitz M, Ruane P, Spinosa-Guzman S, Lefebvre E; POWER 1 and 2 study groups. 2007. Efficacy and safety of darunavir-ritonavir at week 48 in treatmentexperienced patients with HIV-1 infection in POWER 1 and 2: A pooled subgroup analysis of data from two randomised trials. Lancet 369:1169-1178.

DHHS. 2015. Panel on antiretroviral guidelines for adults and adolescents. Guidelines for the use of antiretroviral agents in HIV-1 infected adults and adolescents. Department of Health and Human Services. Available at: https://aidsinfo.nih.gov/contentfiles/lvguidelines/adultandadolescentgl.pdf

EACS. 2015. European AIDS Clinical Society. Guidelines version 8.0 October 2015. Available at: http://www.eacsociety.org/files/guidelines_8_0-english_web.pdf

Gazzard B, Hill A, Anceau A. 2011. Cost-efficacy analysis of the MONET trial using UK antiretroviral drug prices. Appl Health Econ Health Policy 9:217-223.

Katlama C, Valantin MA, Algarte-Genin M, Duvivier C, Lambert-Niclot S, Girard PM, Molina JM, Hoen B, Pakianather S, Peytavin G, Marcelin AG, Flandre P. 2010. Efficacy of darunavir/ritonavir maintenance monotherapy in patients with HIV-1 viral suppression: A randomized open-label, noninferiority trial, MONOI-ANRS 136. AIDS 24:2365-2374.

Madruga JV, Berger D, McMurchie M, Suter F, Banhegyi D, Ruxrungtham K, Norris D, Lefebvre E, de Béthune MP, Tomaka F, De Pawn M, Vangeneugden T, Spinosa-Guzman S; TITAN Study Group. 2007. Efficacy and safety of darunavir-ritonavir compared with that of lopinavir-ritonavir at 48 weeks in treatment-experienced, HIV-infected patients in TITAN: A randomised controlled phase III trial. Lancet 370:49-58.

Ortiz R, Dejesus E, Khanlou H, Voronin E, van Lunzen J, Andrade-Villanueva J, Fourie J, De Meyer S, De Pauw M, Lefebvre E, Vangeneugden T, Spinosa-Guzman S. 2008. Efficacy and safety of once-daily darunavir/ritonavir versus lopinavir/ritonavir in treatment-naive HIV-1 infected patients at week 48. AIDS 22:1389-1397.

Panel de expertos de GeSIDA y Plan Nacional sobre el Sida. 2015. Documento de consenso de GeSIDA/Plan Nacional sobre el Sida respecto al tratamiento antirretroviral en adultos con infección por el virus de la inmunodeficiencia humana (Actualización enero 2015). Enferm Infecc Microbiol Clin 33:544-556.

Poveda E, Blanco F, García-Gascó P, Alcolea A, Briz V, Soriano V. 2006. Successful rescue therapy with darunavir (TMC114) in HIV-infected patients who have failed several ritonavir-boosted protease inhibitors. AIDS 20:1558-1560.

Poveda E, Vispo E, Pattery T, de Mendoza C, Villacian J, Soriano V. 2007. Impact of baseline protease genotype and phenotype on the response to darunavir outside clinical trials. J Antimicrob Chemother 60:1411-1413. 
Rabi SA, Laird GM, Durand CM, Laskey S, Shan L, Bailey JR, Chioma S, Moore RD, Siliciano RF. 2013. Multi-step inhibition explains HIV-1 protease inhibitor pharmacodynamics and resistance. J Clin Invest 123:3848-3860.

Raffi F, Babiker AG, Richert L, Molina JM, George EC, Antinori A, Arribas JR, Grarup J, Hudson F, Schwimmer C, Saillard J, Wallet C, Jansson PO, Allavena C, Van Leeuwen R, Delfraissy JF, Vella S, Chêne G, Pozniak A; NEAT001/ANRS143 Study Group. 2014. Ritonavir-boosted darunavir combined with raltegravir or tenofovir-emtricitabine in antiretroviral-naïve adults infected with HIV-1: 96 week results from the NEAT001/ANRS143 randomised non-inferiority trial. Lancet 384:1942-1951.

Ribeiro KM, Biscione FM, Westin MR, Machado DP, Greco DB, Tupinambás U. 2014. Virologic and immunologic effectiveness of darunavir-based salvage therapy in HIV-1 infected adults in a Brazilian clinical practice setting: Results of a multicentre and retrospective cohort study. Braz J Infect Dis 18:1-7.

Santos JR, Moltó J, Llibre JM, Negredo E, Bravo I, Ornelas A, Clotet B, Paredes R. 2012. Antiretroviral simplification with darunavir/ritonavir monotherapy in routine clinical practice: Safety, effectiveness, and impact on lipid profile. PLoS ONE 7:e37442.

Vingerhoets J, Calvez V, Flandre P, Marcelin AG, Ceccherini-Silberstein F, Perno CF, Santoro MM, Bateson R, Nelson M, Cozzi-Lepri A, Grarup J, Lundgren J, Incardona F, Kaiser R, Sonnerborg A, Clotet B, Paredes R, Günthard HF, Ledergerber B, Hoogstoel A, Nijs S, Tambuyzer L, Lavreys L, Opsomer M on behalf of the Etravirine Cohort Study Group. 2015. Efficacy of etravirine combined with darunavir or other ritonavir-boosted protease inhibitors in HIV-1-infected patients: An observational study using pooled European cohort data. HIV Med 16:297-306.

Young J, Scherrer AU, Gúnthard HF, Opravil M, Yerly S, Bóni J, Rickenbach M, Fux CA, Cavassini M, Bernasconi E, Vernazza P, Hirschel B, Battegay M. Bucher HC for the Swiss HIV Cohort Study. 2011. Efficacy, tolerability and risk factors for virological failure of darunavir-based therapy for treatmentexperienced HIV-infected patients: The Swiss HIV Cohort Study. HIV Med 12:299-307. 